\title{
Costs and gains of porcelain crab suspension feeding in different flow conditions
}

\author{
Y. Achituv ${ }^{1, *}$, M. L. Pedrotti ${ }^{2}$ \\ ${ }^{1}$ Department of Life Sciences, Bar-Ilan University, Ramat-Gan 52900, Israel \\ ${ }^{2}$ Laboratoire d'Oceanographie Biologique et Ecologie du Plancton Marin, Station Zoologique CNRS, Université Paris 6, \\ INSU, La Darse, F-06230 Villefranche-sur-Mer, France
}

\begin{abstract}
Porcellana longicornis is a filter feeder that changes its feeding mechanism in relation to water flow conditions. In still water and slow flow, it actively sweeps the water with its maxillipeds. As flow speed increases, it switches from active suspension feeding to passive feeding. In low frequency oscillating flow, the crabs rhythmically reorient their suspension feeding fans so that both cup-shaped maxillipeds are upstream. In high frequency oscillating flow, the crabs perform alternate movements of left and right feeding fans, so that $1 \mathrm{fan}$ is extended and the concave face is directed upstream, while the other is withdrawn. In the present study, we estimated the clearance rate and energy absorption of $P$. longicornis in the different flow regimes. The average clearance rate for active feeding, in slow unidirectional flow, was $0.267 \mathrm{l} \mathrm{crab}^{-1} \mathrm{~h}^{-1}$, while in passive feeding, in fast unidirectional flow, the clearance rate was $0.142 \mathrm{l} \mathrm{crab}^{-1} \mathrm{~h}^{-1}$ In oscillating flow at $0.5 \mathrm{~Hz}$, the clearance rate was $0.158 \mathrm{l} \mathrm{crab}^{-1} \mathrm{~h}^{-1}$, while at $0.1 \mathrm{~Hz}$ it was $0.201 \mathrm{l} \mathrm{crab}^{-1} \mathrm{~h}^{-1}$ Using the algal concentrations and the energy conversion factor we calculated the amount of energy gained by the crabs during the different feeding behaviors. The

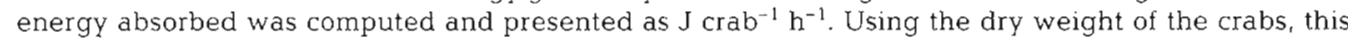
was converted to energy absorbed by a 'standard' crab of $25 \mathrm{mg}$. The oxygen consumption of crabs was estimated as $1.122 \mu \mathrm{mol} \mathrm{O} 2(25 \mathrm{mg} \text { dry } w t)^{-1} \mathrm{~h}^{-1}$ for active feeding; $1.640 \mathrm{\mu mol} \mathrm{O} \mathrm{O}_{2}(25 \mathrm{mg} \text { dry wt })^{-1} \mathrm{~h}^{-1}$ for passive feeding; $0.921 \mu \mathrm{mol} \mathrm{O}_{2}\left(25 \mathrm{mg} \mathrm{dry} \mathrm{wt}^{-1} \mathrm{~h}^{-1}\right.$ for low frequency oscillating current; and $0.829 \mathrm{\mu mol} \mathrm{O}_{2}\left(25 \mathrm{mg}\right.$ dry $\mathrm{wt}^{-1} \mathrm{~h}^{-1}$ for high frequency oscillating flow. However there was no significant difference between oxygen consumption during the different flow conditions. The average heat production for all the experiments was $0.5454 \pm 0.3096 \mathrm{~J} \mathrm{crab}^{-1} \mathrm{~h}^{-1}$ or $0.5353 \pm 0.3734 \mathrm{~J}(25 \mathrm{mg} \text { dry wt })^{-1}$ $\mathrm{h}^{-1}$. The energy budget of $P$. longicornis during the different behaviors was computed, and it was found that the highest energy gain is during active feeding. The higher energy input is contributed by grazing, and not by low heat production. It is suggested that this behavior is an adaptation to life under stones where flow is limited and particulate organic matter is supplied by the activity of the crabs.
\end{abstract}

KEY WORDS: Suspension feeding · Porcelain crabs · Energy budget · Flow $\cdot$ Porcellana

\section{INTRODUCTION}

Suspension feeding is a widespread mechanism for obtaining energy from the water column (Jørgensen 1966). Many benthic marine suspension-feeding organisms that inhabit shallow water, wave-swept habitats normally experience highly variable water flow. Water movement is critical for suspension feeders since it delivers food and oxygen and removes wastes.

•E-mail: achity@mail.biu.ac.il
Flow direction and speed are constantly and rapidly changing in shallow water. On the basis of the source of energy that drives food particles Jørgensen (1966) divided suspension feeding organisms into 2 categories. Active suspension feeders are those which use metabolic energy to drive the current. Passive suspension feeders depend on ambient water movement to drive water past their filtering structures

Observations on the feeding behavior of Porcellana longicornis were described as early as the middle of the 19th century. Nicol (1932) gave a detailed description of the structure of mouth parts and their role in 
feeding. These crustaceans catch suspended food with 2 collecting fans formed by setae of the third maxillipeds (Nicol 1932, Kropp 1981, 1986). Stevcic (1988) suggested that porcelain crabs, in addition to suspension feeding, probably also take larger particles directly from the bottom. Recent work performed in flow tanks simulating natural flow conditions indicates that many details of suspension feeding in variable flow still remain to be understood and suggests that some benthic suspension feeders are much more efficient at processing food-carrying water than has been previously suspected. Suspension feeding mechanisms and their relationship to foraging efficiency and ecological impact need to be described in a specific, quantifiable fashion under a broad range of conditions representing natural flow regimes

Trager et al. (1992) and Trager \& Genin (1993) studied the feeding behavior of barnacles and of 2 porcelain crabs Petrolistes oschimai and P. leptochelys, in flow tanks, in different flow conditions. They showed that the porcelain crabs are able to change their feeding mechanism in relation to flow regime. At a low flow rate, the crabs actively sweep the water with their maxillipeds. The acceleration of flow induces a switch from active feeding to passive feeding. At an intermediate water velocity of $3.5 \mathrm{~cm} \mathrm{~s}^{-1}$, the crabs show mixed behavior, i.e. a mixture of both active and passive behavior. In low frequency oscillating flow, the crabs rhythmically reorient their suspension feeding fans so that the concave side of both cup-shaped maxillipeds is facing upstream. The frequency of the cyclic motions of feeding appendages matches the frequency of flow directional oscillation (Trager et al 1992). In high frequency oscillating flow the crabs perform alternate movements of left and right feeding fans, so that 1 fan is extended and the concave side is facing upstream, while the other is withdrawn. Miller et al. (1992) observed similar behavior in the mole crab Emerita talpoida. These authors presented a survey of feeding behavior of 17 species of benthic organisms, including E. talpoida, in different oscillatory flow and sediment fluxes. They showed that crabs, which burrowed into the sand perpendicular to the flow axis, could feed on both parts of the wave cycle by rotation of the second antennae through $180^{\circ}$.

Trager et al. (1992) and Trager \& Genin (1993) showed that the time allocation of the components of feeding behavior varies with flow velocity and with flow oscillation frequency. Trager \& Genin (1993) hypothesized that the ability to switch feeding modes in response to increased water velocity enhances energetic feeding efficiency. In fast flow, when porcelain crabs extend their fans into the water, they are likely to catch more food per unit time than during active feed- ing. This is due to the increased flux of food with water velocity and to the reduced energetic expenditure in passive feeding. The proportion of total feeding time, during which their fans are collecting food, is about 4 times greater in passive feeding than during active feeding. Trager et al. (1994) suggested that the capture rate can be calculated as follows

$$
R=C \times S \times A \times E
$$

where $R$ is the feeding rate, $C$ is the prey concentration, $S$ is the flow speed through the filter, $A$ is the plane projection of filter area, and $E$ is the filter capture efficiency.

In oscillating flow, the fans are held stationary across the flow for a greater fraction of time in low frequency oscillating flow than in high frequency oscillating flow. If the energetic gain is a function of food-catching time, one would predict that, for low frequency oscillating current, the feeding efficiency would be higher and the amount of food collected in low frequency oscillating flow would be higher than in fast oscillating water.

The energy cost of suspension feeding is an important bioenergetic parameter because suspension feeders process large volumes of water to obtain their food. Jørgensen (1966) suggested that suspension feeding is an energetically marginal way of living in the sea, but there is little information on the energetic cost of this process. This author (Jørgensen 1966) summarized the physiology of suspension feeding in bivalves and planktonic crustaceans.

In recent years, there have been a number of studies which examine food uptake and oxygen demand with respect to suspension feeding. Riisgård (1989) studied the filtration rate and energy cost in the polychaete Chaetopterus variapedatus; Riisgård \& Iversson (1990) studied the same aspects in Sabella penicillus. These 2 polychaetes are active feeders that obtain particulated organic matter by ciliary activity. In $C$. variapedatus, a 'standard' polychaete $(50 \mathrm{mg}$ dry wt) consumed $1 \mathrm{ml}$ of oxygen for filtration of 25 to $50 \mathrm{l}$ of water. The water processing capacity of $S$. penicillus is estimated as $354 \mathrm{l}$ of water per ml of oxygen consumed, suggesting that these polychaetes are adapted to living in water with an extremely low food concentration. Sanderson \& Cech (1992) compared the energetic cost of suspension feeding versus particulate feeding in fish. They demonstrated that oxygen consumption did not differ significantly between these 2 modes of feeding. Atkinson et al. (1994) also found similar results in colonies of the coral Porites compressa in Hawaii. They studied the effect of water velocity on oxygen consumption of colonies of the coral in a water flume and found that respiration rate was not correlated with water velocity. 
In the present study, we quantified the feeding efficiency of porcelain crabs by exposing them to different flow patterns and measuring their feeding rate and the energetic cost and gain of the different feeding modes and computed the energy left, i.e. scope for growth. We tested the hypothesis of Trager \& Genin (1993) that passive feeding is more efficient than is active feeding. This problem is related to the conceptual question whether optimal foraging governs the behavior of suspension feeders. Passive feeding in high flow and in oscillating flow is analog to ambush predation while active feeding in slow flow is analog to cruising predation. We also tested the suggestion of Trager et al. (1992) and Trager \& Genin (1993) that in slow oscillating water the energetic gain of the crabs is higher than in fast oscillating water.

\section{MATERIAL AND METHODS}

Crabs. Porcellana longicornis were collected from under stones at depths of about 1 to $1.5 \mathrm{~m}$ in front of the Station Zoologique, Villefranche-sur-Mer, France. The crabs were kept in unfiltered running seawater, with no food added, and could hide under stones collected from the sea. All experiments were carried out within $10 \mathrm{~d}$ after collection. 18 to $24 \mathrm{~h}$ prior to the experiment the crabs were transferred to filtered seawater. This prevented the production of fecal pellets at the time of the experiments. During the experiments the crabs were fed with Dunaliella tertiolecta (Chlorophyceae). The algae were grown in natural filtered seawater enriched with the F/2 medium of Guillard \& Ryther (1962).

Experimental flow regime. Experiments were conducted in filtered seawater $(0.45 \mu \mathrm{m})$ in a small recirculating flow tank based on the Vogel \& LaBarbera (1978) flow tank. For feeding experiments we used an open flow tank, while for oxygen consumption experiments we used a 'closed' flow tank. A $12 \mathrm{~V}$ DC motor produced water movement; the motor speed was controlled by an electronic function generator. The motor can spin in either direction, depending on whether the current is negative or positive. Computer programs that were interfaced through a digital to analog circuit controlled the motor (Trager et al. 1994)

At the end of each feeding experiment the movement of water flow was visualized by following the movement of brightly illuminated particles that were added to the water. The water velocity was recorded using a videocam (Sony CCD 700E, Hi8 PAL system) with a close-up lens. A ruler was first video-recorded and then the particles were added to the water. Water movement was recorded for about $1 \mathrm{~min}$. At the end of the first recording water was added to the tank to replace the water taken for measurements of algal concentration during the experiments. The volume of water was equal to that at the beginning of the experiment, i.e. $1 \mathrm{l}$ and flow velocity was again recorded. Flow velocity and oscillation frequency were measured by frame-to-frame tracking of the movement of the back-Iit particles suspended in the flowing water, as described by Trager et al. (1990)

Food consumption and clearance rate calculation. At the beginning of the feeding experiment, 11 of water was added to the tank and the motor was run for about $5 \mathrm{~min}$. Samples of water were taken and the concentration of particles 5 to $15 \mu \mathrm{m}$ diameter was determined using a Coulter Multisizer II. If particle concentration was above $100 \mathrm{ml}^{-1}$ the water was replaced. A culture of Dunaliella was added to the water so that the final concentration was about 10000 cells $\mathrm{ml}^{-1}$. To determine the decrease in algal concentration in the water due to sinking of the algae, 3 runs with the lowest flow velocity used in the experiments were conducted at the beginning of the experiments. This was found to be negligible. In addition, at the beginning of each experimental run, samples were taken for determination of algal deposition rate. Deposition rate was found to be negligible. Four crabs were then added to the tank and particle concentration was determined after about 5 min. For determination of algal depletion 3 samples of $10 \mathrm{ml}$ each were taken every $10 \mathrm{~min}$ and the concentration of algae was determined. If the 2 first measured samples yielded similar results, i.e. not more than a $2 \%$ difference, then the concentration of algae in the third sample was not determined. After measurement, the water was returned to the flow tank in order to reduce the changes in water volume, which affects flow velocity in the tank. The volume used by the Coulter counter for each measurement was about $3.5 \mathrm{ml}$. The experiment lasted for about $1 \mathrm{~h}$.

At the end of the experiments, the width and length of the carapace of the crabs were measured with a sliding caliper to an accuracy of $\pm 0.02 \mathrm{~mm}$. The sex of the crabs was recorded and the eggs were removed from gravid females. The crabs were then washed with distilled water, oven-dried in pre-weighed aluminum foil at $60^{\circ} \mathrm{C}$ for $2 \mathrm{~d}$ and then weighed on a Mettler balance with an accuracy of $0.1 \mathrm{mg}$.

For estimation of the algal depletion rate, the regression line describing the decrease in the algal concentration with time was calculated using the data obtained from algal counts. Clearance rate was calculated using the equation given by Coughlan (1969)

$$
C r\left(\mathrm{l} \mathrm{h}^{-1}\right)=V \times\left(\ln C_{1}-\ln C_{2}\right) / \mathrm{d} t
$$

where $C r$ is the clearance rate, $V$ is the volume of water, $C_{1}$ and $C_{2}$ are the concentrations of algae in 


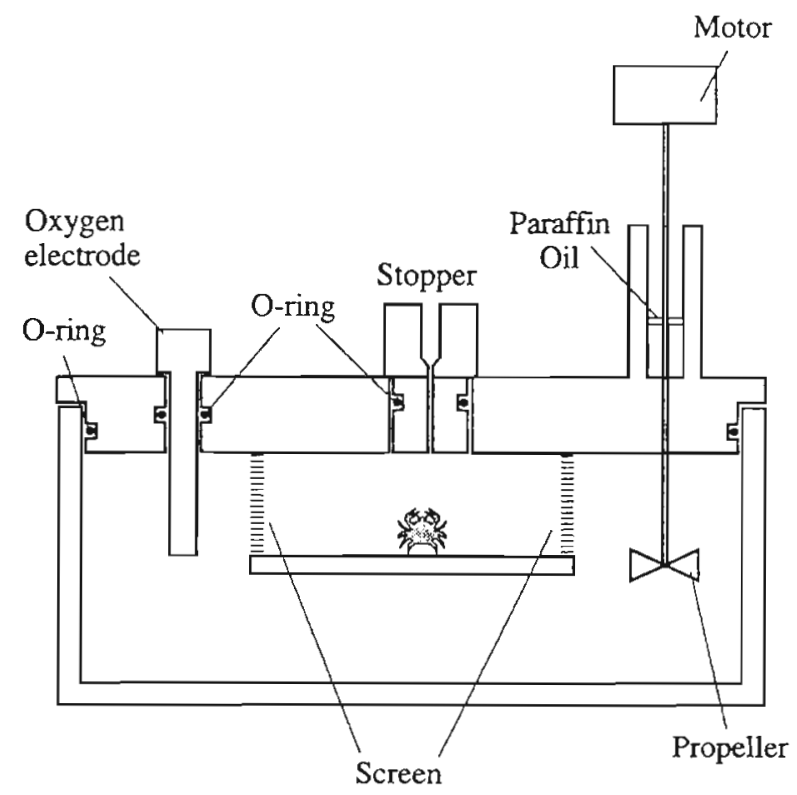

Fig. 1. Mid longitudinal section in the flow tank used for measurement of oxygen consumption of crabs. The flow tank is a modification of the Vogel \& LaBarbera (1978) recirculating flow tank. The size of the tank is reduced and it is built out of a rectangular parallelepiped divided by a horizontal plate into an upper and a lower part. The crabs are kept in the upper part of the tank. Two screens at the edge of the horizontal partition serve as collimators and also prevent the crabs from moving to the lower part of the tank. A propeller, driven by a shaft that runs through a Plexiglas tube and a hole in the cover at one end of the tank, circulates the water in the tank. The propeller is powered by a $12 \mathrm{~V}$ DC motor controlled by a computer program through a digital to analog electronic circuit. The tank is closed and the cover sealed with an O-ring. An oxygen electrode is placed at one end of the tank; after the tank is closed it is filled with air-saturated seawater and the oxygen concentration is measured for 20 min, then the crabs are added through a hole in the middle of the cover and the hole is sealed with a capillary drilled stopper. A few drops of paraffin oil are added to the tube containing the propeller shaft in order to prevent air leaking into the tank. A similar, larger tank without a cover was used for the feeding experiments

cells per $\mathrm{ml}$ at the beginning and end of the time increment, and $\mathrm{d} t$ is the time interval, in hours, between the 2 samples. The initial volume was 11 . However, during the experiment the volume of water in the flow tank was changed by $3.5 \mathrm{ml}$ for each sample measured by the Coulter Multisizer. The volume was corrected for each time interval.

Food absorption efficiency. Food absorption efficiency was measured in 10 samples. $100 \mathrm{ml}$ of algal culture of a known cell concentration was filtered through washed, ashed, and pre-weighed GF/C filters. Two concentrations were used. The filters with the algae were washed with $0.5 \mathrm{M}$ of ammonium-format and then dried at $60^{\circ} \mathrm{C}$ for $48 \mathrm{~h}$. Then the filters were weighed, ashed in a furnace at $450^{\circ} \mathrm{C}$ for $6 \mathrm{~h}$, and weighed again for determination of ash-free weight.

For collection of feces, 4 crabs were placed in filtered seawater for $24 \mathrm{~h}$, allowing gut contents, reflecting their previous diet, to be evacuated. The crabs were then transferred to beakers with an algal concentration similar to that used in the feeding experiments, i.e. $\sim 10000 \mathrm{cell} \mathrm{ml}^{-1}$ with slow agitation. After $2 \mathrm{~h}$, the crabs were transferred to filtered seawater. Feces were collected by a pipette and transferred onto washed, ashed and pre-weighed GF/C filters. The feces were than treated like the food algae.

Absorption efficiency was calculated using the ratio method of Conover (1966)

$$
\text { Absorption efficiency }=(F-F C) /[(1-F C) F]
$$

where $F$ is the ratio between ash-free dry weight and the dry weight of food and $F C$ is the ratio between ashfree dry weight and the dry weight of the feces.

Energy conversion. The amount of algae ingested by the crabs was converted to energy consumed, $I$

$$
I=C r \times \mathrm{POM} \times 23
$$

where $\mathrm{Cr}$ is clearance rate in $1 \mathrm{~h}^{-1}$ ind. ${ }^{-1}$, POM is the ash-free weight of the algae in $\mathrm{mg}^{-1} ; 23$ signifies the energy contents $(\mathrm{J})$ of $1 \mathrm{mg}$ ash-free dry weight of algae (Slobodkin \& Richman 1961).

The energy absorbed $(G)$ was

$$
G=C r \times \text { absorption efficiency }
$$

Oxygen consumption. The rate of oxygen consumption by crabs was measured in a small 'closed' flow tank (Fig. 1). The behavior of the crabs within the tank was observed; we did not measure the respiration of crabs at intermediate flow velocity which show mixed behavior. The rate of decline in oxygen concentration in the flow tank was measured by a calibrated oxygen electrode (Beckman, 39557) and a Beckman oxygen analyzer (Model 0260) connected to a chart recorder. Oxygen consumption was calculated from the slope of the line presenting the rate of oxygen consumption over time:

$$
H=\left[c\left(t_{0}\right)-c\left(t_{1}\right)\right] \times V_{r} \times 60 /\left(t_{0}-t_{1}\right)
$$

where $H$ is rate of $\mathrm{O}_{2}$ uptake in $\mu \mathrm{mol} \mathrm{O}_{2} \mathrm{~h}^{-1}, t_{0}$ and $t_{1}$ are the start and finishing times (min) of the measurement period, repectively. $c(t)$ is the concentration of oxygen in the water $\left(\mu \mathrm{mol} \mathrm{O}_{2}\right)$ at time $t$ and $V_{\mathrm{r}}$ is the volume of the respirometer.

At the beginning of each experimental run the changes in oxygen concentration in water without crabs were recorded for $20 \mathrm{~min}$; these were found to be negligible. Four crabs were then added to the experimental tank and the decline in oxygen concentration was recorded for about $1 \mathrm{~h}$. 


\section{RESULTS}

The feeding behavior of Porcellana longicornis was related to water velocity. At flow rate 1.7 to $2.6 \mathrm{~cm} \mathrm{~s}^{-1}$ all crabs performed active feeding in which the maxillipeds of the crabs were swept rhythmically through the water. When water was accelerated and exceeded $11.5 \mathrm{~cm} \mathrm{~s}^{-1}$ the crabs switched to passive suspension feeding, and the maxillipeds were extended in a stationary fan-like position in which the cancave side of the extended maxillipeds faced into the flow. At an intermediate water velocity of 3.8 to $6.1 \mathrm{~cm} \mathrm{~s}^{-1}$ the crabs showed mixed behavior, switching from time to time from an active to a passive mode of feeding. In low frequency oscillating flow of $-0.1 \mathrm{~Hz}$, and $16 \mathrm{~cm}$ $\mathrm{s}^{-1}$ maximum flow rate, the maxillipeds move simultaneously facing the oncoming flow. In high frequency oscillating water, of $\sim 0.5 \mathrm{~Hz}$, and maximum water velocity of $15 \mathrm{~cm} \mathrm{~s}^{-1}$, the crabs performed rhythmic alternating motions of the left and right feeding fans.

In preliminary experiments using crabs of different sizes, we found that there is a relationship between the size of the crab and its grazing rate. We therefore selected crabs of similar size, about $4.5 \mathrm{~mm}$ carapace width. Analysis of variance (ANOVA) showed that, within the experimental crabs, the decrease of algal concentration with time is not affected by the weight of the crabs $(p=0.2037)$.

The rate of decrease in algal concentration, under 5 different flow regimes, fit a linear regression equation.

The slopes of regression of logarithmically transformed algal concentration versus time, for each crab, which describe the rates of decrease in algal concentration, in the different experiments, under different flow conditions and different behaviors, are presented in Table 1. ANOVA of the data shows that the difference between the algal depletion rate at different flow conditions is significant ( $F=8.46 ; \mathrm{df}=4,23 ; \mathrm{p}>0.0002$ ). Duncan's multiple range test (Table 1) show that there is significant difference between algal depletion rate during active feeding and all 4 other behaviors.

For calculation of the energy gained by the crabs under the different flow patterns we calculated the clearance rate during each time interval (about $10 \mathrm{~min}$ ), using the equation of Coughlan (1969). The inconsistent behavior of the crabs during the entire period of the experiment introduces some difficulties into the calculation of the clearance rate. There are periods of low clearance rate and periods of high feeding rates. These represent periods during which most of the crabs were feeding most of the time and periods of a pause in feeding activity and periods when only some of the crabs were feeding. Therefore, for computing the energy gain, we adopted the approach of Navarro \& Widdows (1997) and used the maximal values of clearance rate obtained during each experiment. The average values of maximal clearance rate are presented in Table 2 . The average clearance rate for active feeding was 0.267 l $\mathrm{crab}^{-1} \mathrm{~h}^{-1}$, while in passive feeding the clearance rate was $0.142 \mathrm{l} \mathrm{crab}^{-1} \mathrm{~h}^{-1}$. In oscillating flow at $0.5 \mathrm{~Hz}$, the clearance rate was $0.158 \mathrm{l} \mathrm{crab}^{-1} \mathrm{~h}^{-1}$, while at $0.1 \mathrm{~Hz}$ it was $0.201 \mathrm{lcrab}^{-1} \mathrm{~h}^{-1}$. ANOVA analysis of the maximal clearance rate shows that there are significant differences between the maximal clearance rates under different flow regimes $(F=5.51 ; \mathrm{df}=4,23 ; \mathrm{p}<0.0029)$. Duncan's multiple range test shows that maximal clearance rate by actively feeding crabs is significantly different from that of all the other behaviors.

Table 1. Porcellana longicomis. Rate of decrease $\left(\mathrm{h}^{-1}\right)$ of algal concentration per crab, calculated from the logarithmic transformation of algal concentration, under different flow conditions and different behaviors; $\mathrm{n}$ is the number of measurements in each experiment. For unidirectional flow mean velocities are given; for oscillating flow mean frequencies and mean maximum flow velocities are presented. Duncan's multiple range test for algal depletion rate; means with the same letter are not significantly different from each other

\begin{tabular}{|c|c|c|c|c|c|c|c|c|c|c|c|c|c|c|c|}
\hline & \multicolumn{3}{|c|}{$\begin{array}{c}\text { Active } \\
\left(2.4 \mathrm{~cm} \mathrm{~s}^{-1}\right)\end{array}$} & \multicolumn{3}{|c|}{$\begin{array}{c}\text { Mixed } \\
\left(5.0 \mathrm{~cm} \mathrm{~s}^{-1}\right)\end{array}$} & \multicolumn{3}{|c|}{$\begin{array}{c}\text { Passive } \\
\left(17.5 \mathrm{~cm} \mathrm{~s}^{-1}\right)\end{array}$} & \multicolumn{3}{|c|}{$\begin{array}{c}\text { Low frequency } \\
\text { oscillations } \\
\left(0.1 \mathrm{~Hz}, 16 \mathrm{~cm} \mathrm{~s}^{-1}\right)\end{array}$} & \multicolumn{3}{|c|}{$\begin{array}{c}\text { High frequency } \\
\text { oscillations } \\
\left(0.5 \mathrm{~Hz}, 15 \mathrm{~cm} \mathrm{~s}^{-1}\right)\end{array}$} \\
\hline & Rate & $r^{2}$ & $\mathrm{n}$ & Rate & $\mathrm{r}^{2}$ & $\mathrm{n}$ & Rate & $r^{2}$ & $\mathrm{n}$ & Rate & $\mathrm{r}^{2}$ & $\mathrm{n}$ & Rate & $r^{2}$ & $\mathrm{n}$ \\
\hline & 1.180 & 0.992 & 9 & 0.926 & 0.976 & 7 & 0.667 & 0.960 & 7 & 0.254 & 0.897 & 8 & 0.812 & 0.971 & 7 \\
\hline & 1.118 & 0.997 & 7 & 0.499 & 0.963 & 7 & 0.267 & 0.910 & 8 & 0.420 & 0.970 & 8 & 0.862 & 0.997 & 7 \\
\hline & 0.742 & 0.982 & 9 & 0.510 & 0.957 & 7 & 0.401 & 0.962 & 8 & 0.512 & 0.984 & 7 & 0.241 & 0.988 & 7 \\
\hline & 1.153 & 0.994 & 8 & 0.291 & 0.988 & 7 & 0.415 & 0.975 & 8 & 0.370 & 0.969 & 7 & 0.384 & 0.974 & 6 \\
\hline & 0.778 & 0.990 & 9 & 0.498 & 0.969 & 6 & 0.380 & 0.991 & 6 & 0.382 & 0.928 & 7 & 0.413 & 0.957 & 7 \\
\hline & & & & 0.572 & 0.997 & 7 & & & & 0.257 & 0.992 & 7 & & & \\
\hline $\begin{array}{l}\text { Mean algal } \\
\text { depletion rate }\end{array}$ & & 0.994 & & & 0.545 & & & 0.426 & & & 0.366 & & & 0.543 & \\
\hline $\mathrm{SD}$ & & 0.215 & & & 0.208 & & & 0.147 & & & 0.099 & & & 0.277 & \\
\hline Duncan's grouping & & B & & & A & & & A & & & A & & & A & \\
\hline
\end{tabular}


Table 2. Porcellana longicornis. Maximum clearance rate data (according to Coughlan 1969) under different flow conditions and different behaviors; for flow conditions see Table 1. Data are expressed in $1 \mathrm{crab}^{-1} \mathrm{~h}^{-1}$. Letters represent Duncan's multiple range test for clearance rate. Means with the same letter are not significantly different

\begin{tabular}{|cccccc|}
\hline & Active & Mixed & Passive & $\begin{array}{c}\text { Low frequency } \\
\text { oscillations }\end{array}$ & $\begin{array}{c}\text { High frequency } \\
\text { oscillations }\end{array}$ \\
\hline & 0.286 & 0.200 & 0.118 & 0.170 & 0.262 \\
& 0.185 & 0.193 & 0.116 & 0.139 & 0.163 \\
& 0.313 & 0.164 & 0.119 & 0.139 & 0.190 \\
& 0.235 & 0.102 & 0.110 & 0.215 & 0.124 \\
& 0.319 & 0.239 & 0.248 & 0.079 & 0.268 \\
Average & 0.267 & 0.197 & & 0.130 & \\
SD & 0.057 & 0.062 & 0.059 & 0.153 & 0.063 \\
Duncan's & $\mathrm{A}$ & $\mathrm{B}$ & $\mathrm{B}$ & $\mathrm{B}$ & $\mathrm{B}$ \\
grouping & & & & & 0.158 \\
\hline
\end{tabular}

1 crab and of a 'standard' crab of $25 \mathrm{mg}$ dry weight. ANOVA indicates that there is no significant difference between oxygen consumption under the different flow regimes, both when the results are presented as $\mu \mathrm{mol} \mathrm{O}_{2}$ $\mathrm{Crab}^{-1} \mathrm{~h}^{-1}(F=1.33 ; \mathrm{df}=3,24 ; \mathrm{p}<$ $0.287)$ or $\mathrm{mol} \mathrm{O}_{2}(25 \mathrm{mg} \text { dry } w \mathrm{t})^{-1} \mathrm{~h}^{-1}$ $(F=1.40 ; \mathrm{df}=3,32 ; \mathrm{p}<0.269)$. Oxygen uptake was converted to energy by using the heat equivalent of oxygen

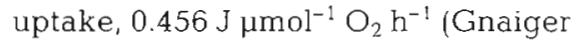
1983). The average heat production for all the experiments was $0.545 \pm$ $0.310 \mathrm{~J} \mathrm{crab}^{-1} \mathrm{~h}^{-1}$ or $0.535 \pm 0.373 \mathrm{~J}$ (25 mg dry $w)^{-1} \mathrm{~h}^{-1}$. Since there was no significant difference in the oxygen consumption between the different flow regimes we used the total aver-

The dry weight of Dunaliella tertiolecta was $3.203 \times$ $10^{-7} \pm 6.501 \times 10^{-8} \mathrm{mg} \mathrm{cell}{ }^{-1}$ or $32.03 \mathrm{mg} \times 10^{6}$ cells $(\mathrm{n}=$ 9). The ash free dry weight was $20.25 \pm 2.05 \mathrm{mg} \times 10^{6}$ cells. The percentage of organic matter in the algae was $69.37 \pm 11.72$. The percentage of organic matter in the feces was $36.56 \pm 11.50(n=16)$. The absorption efficiency is therefore 0.726 . Using the conversion factor of $23 \mathrm{~J} \mathrm{mg}^{-1}$ ash-free dry weight of algae (Slobodkin \& Richman 1961) we calculated the amount of energy gained by the crabs at the different feeding behaviors. The values presented in Table 3 are expressed in the amount of energy obtained by a crab. Using the dry weight of the crabs these values were converted to the amount of energy consumed and absorbed by a 'standard' crab of $25 \mathrm{mg}$ dry weight, which is about the average weight of the crabs used in our experiments.

The oxygen consumption and heat production of the crabs are presented in Table 4 , as the oxygen uptake of age for calculation of heat production for all experiments. The data on heat production, together with the data on food absorption, were used for the construction of energy budgets under the different flow regimes. The energy budgets are given in Table 5. The highest energy gain and scope for growth is found in actively feeding crabs; the higher energy input is contributed by grazing.

\section{DISCUSSION}

Suspension-feeding organisms obtain food particles from the water by passing water through body parts advances that have been made in predicting the physical mechanism of particle capture operating at the level of individual filter elements (Shimeta \& Jumars that act as filters. Despite the significant theoretical

Table 3. Porcellana longicornis. Energy consumption at different flow regimes and different behaviors, based on maximum clearance rate data in Table 2 , and the concentration of algae in the flow tank. The amount of algae is converted to its energetic value using the conversion factor $1 \mathrm{mg}$ ash-free dry weight of algae is equivalent to $23 \mathrm{~J}$ (Slobodkin \& Richman 1961 ) calculated as energy consumed by a crab and by a standard crab of $25 \mathrm{mg}$ dry weight. Using the amount of organic matter in the feces, the energy absorbed is calculated. For flow conditions see Table 1

\begin{tabular}{|c|c|c|c|c|c|}
\hline & Slow flow (active) & Intermediate (mixed) & Fast flow (passive) & Slow oscillation & Fast oscillation \\
\hline $\begin{array}{l}\text { Energy consumed } \\
\left(\mathrm{J} \mathrm{crab}^{-1} \mathrm{~h}^{-1}\right)\end{array}$ & $8.98 \pm 1.72$ & $7.39 \pm 1.95$ & $4.78 \pm 1.84$ & $5.87 \pm 1.97$ & $7.08 \pm 2.48$ \\
\hline $\begin{array}{l}\text { Energy absorbed } \\
\left(\mathrm{J} \mathrm{crab}^{-1} \mathrm{~h}^{-1}\right)\end{array}$ & $3.22 \pm 0.62$ & $2.65 \pm 0.70$ & $1.72 \pm 0.65$ & $2.11 \pm 0.7 .1$ & $2.54 \pm 0.89$ \\
\hline $\begin{array}{l}\text { Energy consumed } \\
\left(\mathrm{J} 25 \mathrm{mg}^{-1} \mathrm{~h}^{-1}\right)\end{array}$ & $8.32 \pm 2.96$ & $9.38 \pm 2.89$ & $6.48 \pm 2.96$ & $4.93 \pm 1.56$ & $6.45 \pm 2.96$ \\
\hline $\begin{array}{l}\text { Energy absorbed } \\
\text { standard } \operatorname{crab}\left(\mathrm{J} 25 \mathrm{mg}^{-1} \mathrm{~h}^{-1}\right)\end{array}$ & 1) $2.99 \pm 1.06$ & $3.37 \pm 1.04$ & $2.32 \pm 1.09$ & $1.77 \pm 0.63$ & $2.31 \pm 1.06$ \\
\hline
\end{tabular}




\begin{tabular}{|c|c|c|}
\hline 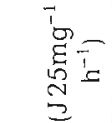 & 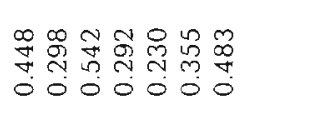 & $\begin{array}{l}\infty \\
m \\
\infty \\
0\end{array}$ \\
\hline 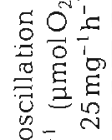 & 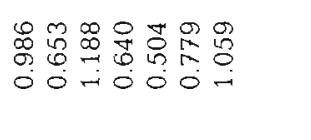 & 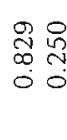 \\
\hline 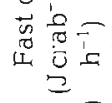 & 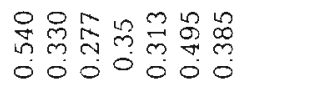 & $\begin{array}{l}15 \\
\infty \\
\infty \\
0 \\
0\end{array}$ \\
\hline 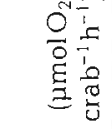 & 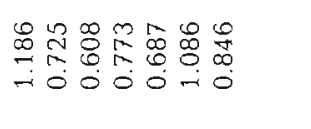 & 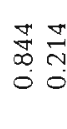 \\
\hline 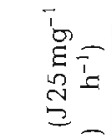 & 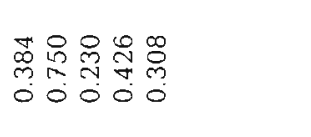 & \begin{tabular}{l}
8 \\
\multirow{2}{*}{$:$} \\
0
\end{tabular} \\
\hline 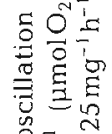 & 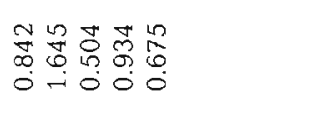 & 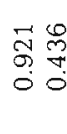 \\
\hline 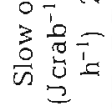 & 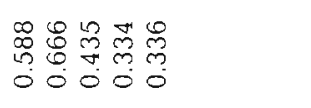 & 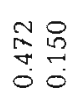 \\
\hline 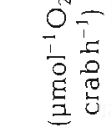 & 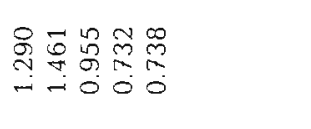 & 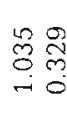 \\
\hline 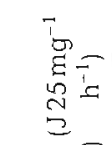 & 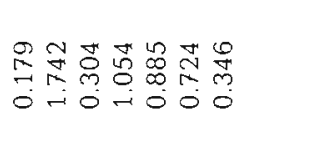 & 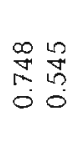 \\
\hline 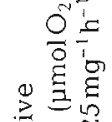 & 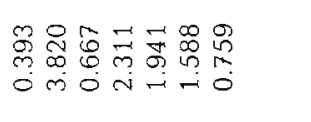 & 융 \\
\hline 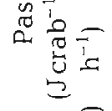 & 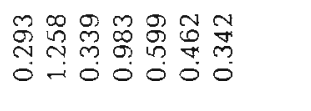 & 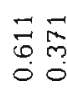 \\
\hline 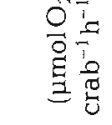 & 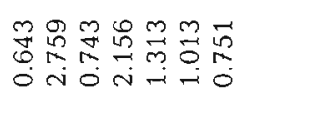 & 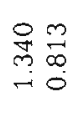 \\
\hline 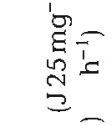 & 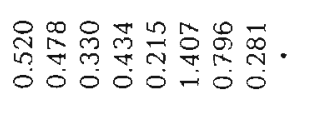 & $\begin{array}{ll}0 & 0 \\
n & \infty \\
n & ? \\
0 & 0\end{array}$ \\
\hline 皇 & 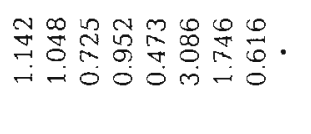 & 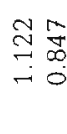 \\
\hline 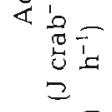 & 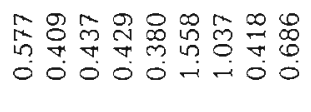 & $\begin{array}{l}0 \\
109 \\
0 \\
0 \% \\
0\end{array}$ \\
\hline$\frac{0^{2} T}{0}$ & 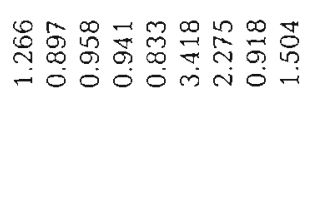 & 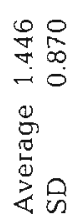 \\
\hline
\end{tabular}

1991, Vogel 1994), there is still a great need for a better understanding of how marine invertebrates work at the organism level. There is a great gap with respect to the quantitative aspects of suspension feeding in a range of conditions representing different flow regimes. In the present work, we have studied the food absorption and oxygen uptake of the porcelain crab Porcellana longicornis and we present an energy budget for this suspension-feeder crab under different flow conditions.

The feeding behavior of Porcellana longicornis is similar to that described by Trager et al. (1992) and Trager \& Genin (1993) for Petrolistes oschimai and $P$. leptochelys. Our results suggest that in $P$. longicornis, feeding at a low flow rate of $2.5 \mathrm{~cm} \mathrm{~s}^{-1}$, when the crabs are actively propelling the water-borne phytoplankton, is a more energetically efficient mechanism than is feeding at a high velocity unidirectional flow rate or in oscillating flow, where particles are passively driven toward the extended maxillipeds. The clearance rate of actively feeding crabs is more than 2 times higher than in passively feeding crabs (Table 2). In oscillating water the feeding rate is higher in high frequency oscillation, when the crabs perform alternate movements of left and right feeding fans, than it is in low frequency oscillating flow, where the crabs rhythmically reorient so that both cup-shaped feeding fans face upstream. These findings are not explained by observations that, in slow oscillating water, the fans are held in a stationary position across the flow for a greater fraction of time than in fast oscillating flow. Trager \& Genin (1993) assumed that energetic gain was partially a function of food-catching time, and therefore supposed that the feeding efficiency would be higher for a slowly oscillating current and that the amount of food collected would be higher than in rapidly oscillating water.

It is hard to explain how active feeding in a low current is more efficient than passive feeding, where the time allocated for foraging is higher. It could be that the reduced clearance rate found in passive feeding, when water velocity is high, is because algae that contact the extended maxillipeds are swept past, rather than retained, by high current. It could also be that oscillating flow speeds are above the optimum flow speed for high particle retention efficiency.

Trager et al. (1994) have suggested that the feeding rate is related to flow speed. However, this does not agree with our findings. It is possible that the current created by the moving fans is higher than that which passes the extended fans. Porcellana longicornis is found, at least during the daytime, under stones where water flow is limited. It is likely that fan movement during active feeding is the main source of small scale currents in this confined space and that it is important in 
Table 5. Porcellana longicornis. Energy budget of crabs exposed to different flow conditions and showing different behaviors. The energy budget is computed from the data of clearance rate (Table 2) and algal concentration converted to its energetic equivalent (Table 3 ) and the heat production calculated from oxygen uptake of all experiments $(\mathrm{n}=27), 0.545 \pm 0.309 \mathrm{~J} \mathrm{crab}^{-1} \mathrm{~h}^{-1}$ and $0.535 \pm 0.373 \mathrm{~J} 25 \mathrm{mg}^{-1} \mathrm{~h}^{-t}$

\begin{tabular}{|c|c|c|c|c|}
\hline & $\begin{array}{c}\text { Energy } \\
\text { absorbed } \\
\left(\mathrm{J} \mathrm{crab}^{-1} \mathrm{~h}^{-1}\right)\end{array}$ & $\begin{array}{c}\text { Energy } \\
\text { absorbed } \\
\left(\mathrm{J} 25 \mathrm{mg}^{-1} \mathrm{~h}^{-1}\right)\end{array}$ & $\begin{array}{c}\text { Energy } \\
\text { gain } \\
\left(\mathrm{J} \mathrm{crab} \mathrm{h}^{-1}\right)\end{array}$ & $\begin{array}{c}\text { Energy } \\
\text { gain } \\
\left.\text { (J } 25 \mathrm{mg}^{-1} \mathrm{~h}^{-1}\right)\end{array}$ \\
\hline Slow flow (active) & $6.54 \pm 1.25$ & $6.04 \pm 2.15$ & $5.97 \pm 1.29$ & $5.51 \pm 2.18$ \\
\hline Fast flow (passive) & $3.47 \pm 1.33$ & $4.71 \pm 1.09$ & $2.92 \pm 1.37$ & $4.17 \pm 1.15$ \\
\hline Slow oscillations & $4.26 \pm 1.43$ & $3.58 \pm 1.28$ & $3.71 \pm 1.48$ & $3.05 \pm 1.33$ \\
\hline Fast oscillations & $5.14 \pm 1.80$ & $4.68 \pm 2.15$ & $4.59 \pm 1.83$ & $4.1 .5 \pm 2.18$ \\
\hline
\end{tabular}

(1989) and Riisgård \& Iversson (1990) showed that polychaetes consume $1 \mathrm{ml}$ of oxygen for clearance of 25 to $354 \mathrm{l}$ of water We calculated the ratio between the water cleared of particles and the oxygen consumption from our results. It was found that Porcellana longicornis consume $1 \mathrm{ml}$ of oxygen for filtration of 0.858 l of water in active feeding; $0.340 \mathrm{l}$ of water in passive feeding; $0.675 \mathrm{l} \mathrm{ml}$ for feeding in slowly oscillating water and $0.9751 \mathrm{ml}$ for feeding in rapidly oscillating water. This again indicates that the cost of feeding is lowest in rapidly oscill-

the supply and renewal of particulate organic matter in this enviromment. The activity of the maxillipeds might be important in the resuspension of particles in the benthic boundary layer. A high efficiency of active feeding can be regarded as an adaptation to life in niches without water movement.

Differences in feeding efficiency due to different flow regimes have been shown in crinoids. Holland et al. (1986) and Leonard et al. (1988) demonstrated the importance of the predominant current pattern in microhabitats with respect to food collection. They studied the feeding habits of the crinoid Oligometra serripinna at several flow speeds and found variations in capture efficiency. Increasing the current speed resulted in a decrease in the proportion of particle deflections and in the proportion of particles passing through the arms. The capture rate was maximal at a current speed similar to that found in the crinoid's microhabitat. Erez (1992) studied feeding in 3 crinoids taken from the coral reefs of the Gulf of Eilat (Red Sea). She found that food capture at low water velocities is low, increasing to a maximum of 3.2 to $5.4 \mathrm{~cm} \mathrm{~s}^{-1}$, which is the ambient flow rate. Lampometra klunzingeri, which inhabits shallow areas, is better adapted to feeding under flow oscillations while Heterometra savignii is adapted to unidirectional flow, which is the most frequent type of flow in the deep water where this crinoid abounds. However, unlike porcelain crabs, crinoids do not evince active propulsion of water but collect their food by means of podia, which are lined with cilia, distributed over their extended arms. The arms are held outstretched in a plane perpendicular to the ambient water flow.

Jørgensen (1975) reviewed the relationship between the water clearance and the oxygen consumption in filter feeding bivalves and planktonic crustaceans. In bivalves, between 79 and 0.2 , but usually from 5 to 16 , liters of water are cleared for each milliliter of oxygen consumed. In planktonic crustaceans, this ratio varies from $30 \mathrm{l}$ in Rhincalanus to $0.1 \mathrm{l}$ in Metridia. Riisgărd ating water. In comparison to the ratios for bivalves, polychaetes and planktonic crustaceans, those found for $P$. longicornis are rather low. This might indicate that suspension feeding is not the only source of food, and that $P$. longicornis is not exclusively a suspension feeder but, as suggested by Stevcic (1988), obtains part of its energy from large particles from the bottom.

In our study we could not demonstrate significant differences in the oxygen consumption under the different flow patterns. This fits the observations of Sanderson \& Cech (1992), who demonstrated that oxygen consumption does not differ in 2 modes of feeding in fish. Atkin son et al. (1994) found that oxygen consumption in a coral was not affected by water velocity. Our findings might be due to the fact that keeping the maxillipeds extended in the flow consumes the same or similar amount of energy as does active feeding. One of the limitations of this study is the need to use several crabs in the experiments. This limits the clarity of the results; in many cases the results represent a mixture of behaviors. During a given time interval some of the crabs may be inactive or may be engaged in a certain behavior, while the others engage in different behavior. This limitation is accentuated in the oxygen uptake experiments, more than in the feeding experiments. In order to obtain a measurable decline in oxygen concentration the volume of the respirometer chamber must be kept small, but in our case there is a minimum limit in the size of the small flume. Moreover, the decline in oxygen within the experimental chamber is recorded over a long period, while in the feeding experiment the decline in algal concentrations is recorded over short periods. In order to overcome this limitation, we suggest using a different, larger species of porcelain crab so that the effect of a single crab on the reduction in oxygen concentration is high enough, and the rate of oxygen uptake can be related to the observed behavior of the crabs. The experimental design should be improved by simultaneously monitoring the cost and gains of feeding under constant video monitoring. 
If there is no difference in oxygen consumption during the different behaviors and if active feeding is the most rewarding feeding mechanism, it is puzzling why crabs should switch to passive feeding at all. We suggest that moving the maxillipeds against the current in fast current is more energy consuming than keeping the fans extended in the fast moving current. This emphasises the need for measurements in feeding experiments at a wide range of flow velocities coupled with oxygen consumption experiments in single crabs and relating them to observed behavior.

Acknowledgements. This study was carried out during a visit of Y.A. to Laboratoire d'Oceanographie Biologique et Ecologie du Plancton Marin, Station Zoologique CNRS, Université Paris 6, Villefranche-sur-Mer, France. The generous hospitality of the staff of the Station Zoologique is greatly appreciated. The authors wish to thank Dr Gaby Gorski for help in use of space and equipment in his laboratory. Mrs Claire Copin helped us with the oxygen meter. We thank Mrs Anne Marie Corre and Mrs Marise Scotto for the algal supply. Mr Bruno Hesse and Mr Sebastian Montreuil helped us in the collection and maintenance of the crabs. Mrs Rachel Levi-Drummer of the Department of Life Sciences, Bar-Ilan University Israel, helped with the statistical analysis. Dr A. Susswein and Dr A. Genin read the manuscript and suggested corrections and improvements

\section{LITERATURE CITED}

Atkinson MJ, Kotler E, Newton P (1994) Effect of water velocity on respiration, calcification and ammonium uptake of a Porites compressa community. Pac Sci 48:296-303

Conover RJ (1966) Assimilation of organic matter by zooplankton. Limnol Oceanogr 11:338-354

Coughlan $J$ (1969) The estimation of filtering rate from the clearance of suspensions. Mar Biol 2:356-358

Erez D (1992) The effect of water flow on suspension feeding crinoids (Echinodermata: Crinoidea). MSc thesis, The Hebrew University of Jerusalem (in Hebrew)

Gnaiger E (1983) Heat dissipation and energetic efficiency in animal anoxibiosis: economy contra power. J Exp Zool 228: $471-490$

Guillard RRL, Ryther JH (1962) Studies of marine plankton diatoms. I. Cyclotela nana Hustedt and Detonula confervacea (Cleve) Gran. Can J Microbiol 8:229-239

Holland ND, Strickler JR, Leonard AB (1986) Particle interception, transport and rejection by the feather star Oligometra serripinna (Echinodermata: Crinoidea), studied by frame analysis of videotapes. Mar Biol 93:111-126

Jørgensen CB (1966) Biology of suspension feeding. Pergamon, Oxford

Editorial responsibility: Otto Kinne (Editor),

Oldendorf/Luhe, Germany
Jørgensen CB (1975) Comparative physiology of suspension feeding. Annu Rev Physiol 37:57-79

Kropp RK (1981) Additiondl porcelain crab feeding methods (Decapoda, Porcellanidae). Crustaceana 40:307-310

Kropp RK (1986) Feeding biology and mouth part morphology of three species of coral gall crabs (Decapoda: Cryptochiridae). J Crustac Biol 6:377-384

Leonard AB, Strickler JR, Holland ND (1988) Effect of current speed on filtration during suspension feeding in Oligometra serripinna (Echinodermata: Crinoidea). Mar Biol 97: $111-125$

Miller DC, Bock MJ, Turner EJ (1992) Deposit and suspension feeding in oscillatory flows and sediment fluxes. J Mar Res 50:489- 520

Navarro JM, Widdows J (1997) Feeding physiology of Cerastoderma edule in response to a wide range of seston concentrations. Mar Ecol Prog Ser 152:175-186

Nicol EAT (1932) The feeding habits of the Galatheidea J Mar Biol Assoc UK 18:87-106

Riisgård HU (1989) Properties and energy cost of the muscular piston pump in the suspension feeding polychaete Chaetopterus variopedatus. Mar Ecol Prog Ser 56 $157-168$

Riisgård HU, Iversson NM (1990) The crown filament pump of the Sabella penicllus: filtration, effect of temperature and energy cost. Mar Ecol Prog Ser 62:249-257

Sanderson SL, Cech JJ Jr (1992) Energetic cost of suspension feeding versus particulated feeding by juvenile Sacramento blackfish. Trans Am Fish Soc 121:149-157

Shimeta J, Jumars PA (1991) Physical mechnism and rates of particle capture by suspension feeders. Oceanogr Mar Biol Annu Rev 29:191-257

Slobodkin LB, Richman S (1961) Calories/gm in species of animals. Nature 191:299

Stevcic Z (1988) Autecological investigations of the porcelain crab Porcellana platycheles (Pennant) (Decapoda, Anomura) in the Rovinj area (northern Adriatic). Crustaceana $55: 242-252$

Trager G, Genin A (1993) Flow velocity induces a switch from active to passive suspension feeding in a porcelain crabs Petrolisthes leptocheles (Heller). Biol Bull 185:20-27

Trager G, Hawang JS, Strickler JR (1990) Barnacle suspension feeding in variable flow. Mar Biol 105:117-127

Trager G, Coughlin D. Genin A, Achituv Y, Gangopadhyay A (1992) Foraging to the rhythm of ocean waves: porcelain crabs and barnacles synchronize feeding motions with flow oscillations. J Exp Mar Biol Ecol 164:73-86

Trager G. Achituv Y, Genin A (1994) Barnacle feeding on copepods and Artemia: effect of prey escape, flow speed and feeding mode of zooplankton capture. Mar Biol 120: $251-259$

Vogel S (1994) Life in moving fluids, 2nd edn. Princeton University Press, Princeton

Vogel S, LaBarbera M (1978) Simple flow tank for research and teaching. BioSci 28:638-643

Submitted: September 2, 1998; Accepted: March 16, 1999

Proofs received from author(s): July 19, 1999 